\title{
Foucault - maoismen, genealogien
}

Det er velkendt, at der i begyndelsen af 1970erne indtræder en iøjnefaldende forskydning i Foucaults terminologi, idet han nu i stigende grad begynder at benytte betegnelsen 'genealogi' om sine historiske analyser af tankesystemernes historie i stedet for som tidligere at beskrive disse som en form for 'arkæologi'. Denne metodiske forskydning bliver sædvanligvis knyttet sammen med en anden forskydning i forfatterskabet, nemlig en tematisk forskydning fra viden til magt(-viden). I receptionslitteraturen forbindes disse to forskydninger ofte med Foucaults egen eksplicitte betoning af sin gæld til Nietzsche som f.eks. i det sidste interview, han gav inden sin død 1984, hvor han kortfattet konstaterer: 'Jeg er ganske simpelt nietzscheaner' (Foucault 1990: 251). ${ }^{1}$ Det er tilsyneladende Nietzsche, særligt hans begreb om 'viljen til sandhed', der giver Foucault (skarpere) blik for, at de pludselige transformationer i de vidensformationer (psykiatrien, klinikken og humanvidenskaberne), som han hidtil havde undersøgt, skulle forstås i sammenhæng med de forandringer, som de samme perioders centrale magtmekanismer havde undergået. Og det er tilsyneladende også Nietzsche, særligt det centrale værk Moralens genealogi, der leverer de grundlæggende analytiske indsigter til Foucaults arbejde med at blotlægge forholdet og sammenspillet imellem vidensproduktion og magtudøvelse.

På den baggrund er det måske ikke så overraskende, at der i receptionslitteraturens behandling af Foucaults begreb om genealogi er en tendens til først og fremmest at læse genealogien som en form for nietəscheansk historieskrivning (f.eks. Minson 1986; Mahon 1992; Owen 1994). Og der synes da heller ikke at være nogen grund til at så tvivl om en sådan læsning - Nietzsches indflydelse på Foucaults syn på og tilgang til historien kan næppe overvurderes. Men som bekendt er enhver læsning, ethvert perspektiv, også altid et (mere eller mindre bevidst) fravalg af en række andre læsninger og perspektiver. Spørgsmålet er, om den åbenlyse forbindelse til Nietzsche måske har været med til at underbetone andre væsentlige 
forbindelser og inspirationskilder i diskussionen af Foucaults genealogiske tilgang?

I denne artikel vil vi fremsætte en læsning af Foucault og hans forhold til historien, som fokuserer på en anden, mindre oplagt, positiv dialogpartner i forfatterskabet, nemlig den marxistiske tradition og særligt den franske maoisme. Når marxismen nævnes $i$ sammenhæng med Foucault, så er det som regel med fokus på hans opgør med den. Og det er ikke uden grund. Man behøver ikke læse ret meget Foucault, og særligt ikke, hvis man (kun) læser de senere og mest populære værker som Overvagning og straf, Viljen til viden og interviewsamlingen Power/Knowledge for at få en klar fornemmelse af, at marxisme ikke er noget decideret plusord i Foucaults bog. Denne modvilje imod marxismen bekræftes af (store dele af) både den 'ortodokse' og den marxistisk funderede reception af Foucault (f.eks. Dreyfus \& Rabinow 1982; Smart 1983; Callinicos 1990; Eagleton 1991). ${ }^{2}$ Men ligesom med så mange andre forhold i Foucaults forfatterskab bør man imidlertid være forsigtig med at drage forhastede konklusioner. For som en række nyere forskningsbidrag peger på, så er Foucaults relation til den marxistiske tradition mere kompliceret end hans kritik af den teoretiske marxisme (rettet mod især dens fremmedgørelsesantropologi, historiesyn, magtopfattelse og ideologibegreb) og hans afstandtagen fra den politiske marxismes dogmatiske former (såvel det franske kommunistparti som stalinismen) umiddelbart kan give indtryk af (Balibar 1992; Macdonald 2002; Paolucci 2002; Olssen 2004; Hunt 2004). ${ }^{3}$

$\mathrm{Vi}$ vil i det følgende inspireret af disse forskningsbidrags mere komplekse billede af Foucaults relation til den marxistiske tradition undersøge to aspekter ved denne relation med særligt henblik på hans genealogiske metode. I første del af artiklen ser vi nærmere på en forholdsvis underbelyst episode i Foucaults forfatterskab, nemlig hans engagement $\mathrm{i}$ den maoistisk funderede og inspirerede organisation Groupe d'information sur les prisons (GIP). Der er vores tese, at Foucaults praktiske erfaringer fra GIP satte sig væsentlige spor $\mathrm{i}$ hans teoretiske udarbejdning af en genealogisk orienteret historieskrivning med fokus på magt-viden. ${ }^{4}$ Som optakt hertil er det imidlertid nødvendigt først at se lidt nærmere på den forudgående anledning til Foucaults engagement i GIP, nemlig det, som han selv kalder for sin 'politiske erfaring' i 1968. I den sidste del af artiklen 
vil vi gennem en nærlæsning af Foucaults mest eksplicitte metodiske overvejelser over sin genealogiske historieskrivning, nemlig forelæsningerne på Collège de France i 1976, vise hvordan arbejdet i GIP afspejles i disse overvejelser. I forhold til den sparsomme, eksisterende udforskning af GIPs og maoismens rolle for Foucaults tænkning (Birch 2008; Wolin 2010; Welch 2010; Hoffman 2012), adskiller nærværende artikel sig derfra ved at fokusere på spørgsmålet om maoismens betydning for genealogien og i forlængelse heraf tilbyder den en mere grundig afdækning af, hvordan særligt de franske maoisters 'undersøgelsesteknik' (enqûete) udgør en væsentlig inspirationskilde for Foucault.

Sigtet med artiklen er således trefoldigt. For det første at bidrage til at sætte fokus på andre (mere eller mindre oversete) inspirationskilder til Foucaults genealogiske tilgang end Nietzsche. For det andet at bidrage til at nuancere opfattelsen af Foucaults forhold til marxismen, der ofte fremstilles som ensidigt kritisk. Og for det tredje konkret at vise, hvordan forskellige principper fra maoisternes politiske aktivisme går igen ikke blot i Foucaults praktiske engagement i GIP, men også i hans teoretiske overvejelser over genealogien.

\section{Marts 68}

Selvom Foucault, der blev født i 1926, ikke tilhører den såkaldte '68-generation', havde 68-oprøret alligevel, som han ved flere lejligheder understreger, en afgørende betydning for ham personligt, og ligeledes for hans tænkning. Uden begivenhederne i 1968 ville det ikke, som han et sted udtaler, have været muligt efterfølgende at udføre arbejdet med kriminalitet og seksualitet (Foucault 2000: 282; Foucault 1980b: 111, 116). Denne tætte forbindelse mellem personlig erfaring og teoretisk praksis, mellem liv og værk, som Foucault antyder i forbindelse med 68-begivenhederne, understreger han eksplicit i et interview fra 1978 som grundlæggende for hele forfatterskabet: 'Jeg har ikke skrevet én eneste bog, som ikke, i hvert fald delvist, har været inspireret af en direkte personlig erfaring" (Foucault 2000: 244). Inden vi ser nærmere på hans 68-erfaring - og herunder spørgsmålet om marxismens rolle heri - skal vi ganske kort berøre Foucaults opfattelse af denne forbindelse mellem erfaring 
og tænkning.

I interviewet fra 1978 beskriver Foucault sine bøger som 'erfaringsbøger'. Det er værd at bemærke, at det franske ord 'expérience' kan betyde både 'erfaring' og 'eksperiment', og at begge betydninger synes at klinge med hos Foucault her. Med erfaringsbøger mener han således flere ting (Foucault 2000: 239-246). For det første er hans bøger erfaringsbøger $\mathrm{i}$ den ovenfor betonede forstand, at de bygger på en personlig erfaring. For det andet er det bøger, der er blevet til gennem en eksperimenterende afsøgning af et interesseeller problemfelt (knyttet til personlig erfaring) snarere end som et forsøg på at kommunikere en allerede fastlagt tanke. For det tredje påpeger Foucault, at hans bøger udgør eller udvirker en erfaring $\mathrm{i}$ den forstand, at de implicerer en transformation af både den, der skriver og den, der læser, disse bøger. Nærmere bestemt, en transformation i henholdsvis forfatterens og læserens måde at forholde sig til ikke blot de emner, bøgerne udforsker, men også til sig selv. Denne opfattelse af hans bøger har - som han selv påpeger - desuden konsekvenser for den metode, han benytter i sin historieskrivning: "Når jeg begynder på en bog ved jeg ikke alene ikke, hvad jeg ender med at tænke i slutningen, men det er heller ikke helt klart for mig, hvilken metode jeg vil benytte. Hver af mine bøger er en måde at udmejsle et objekt og fabrikere en analysemetode på" (Foucault 2000: 240). Foucault berører endvidere en række andre implikationer af denne opfattelse, bl.a. spørgsmål om sandhedsværdien af hans bøger, men det væsentlige for os i denne sammenhæng er at understrege den tætte forbindelse, der tydeligvis eksisterer hos Foucault mellem personlig erfaring og teoretisk praksis.

Når årstallet 1968 kommer på tale i en fransk kontekst, forbinder de fleste det nok først og fremmest med det studenteroprør, der brød ud på den såkaldte 'barrikadernes nat' i Paris den 10. maj, og som resulterede $\mathrm{i}$ en række efterfølgende demonstrationer og generalstrejker. Det er imidlertid ikke tilfældet for Foucault. På tidspunktet for disse optøjer befandt han sig slet ikke i Frankrig, men i Tunesien, hvor han siden 1966 havde varetaget et gæsteprofessorat. Her oplevede Foucault til gengæld i marts 1968, hvordan hans egne studerende med betydelig risiko for liv og lemmer gjorde oprør imod det tunesiske styre (Foucault 2000: 279-281). Disse begivenheder, som Foucault i et vist omfang selv deltog i, påvirkede 
ham dybt: "Jeg var dybt imponeret af disse unge kvinder og mænd, der er udsatte sig selv for frygtelige risici ved at udarbejde en folder, distribuere den, eller opfordre til en strejke. Det var en sand politisk erfaring for mig" (Foucault 2000: 279). Men hvori består så denne 'politiske erfaring' nærmere, hvis vi forstår erfaring i forlængelse af Foucault selv som noget, der konfronterer os med vores egne grænser?

Ja, for det første erfarer Foucault på et praktisk niveau, hvordan de tunesiske studerendes politiske aktivisme involverer en personlig lidenskab og selvopofrelse, som er ham selv ukendt (og som tydeligvis fascinerer ham): "I dagens verden, hvad er det hos mennesker, som kan vække begæret efter, evnen til og muligheden for at yde et absolut offer, uden at der er nogen grund til at mistænke, at der i deres handling ligger den mindste ambition eller det mindste ønske om magt og profit? Det er, hvad jeg så i Tunesien [...]" (Foucault 2000: 280). En af konsekvenserne af denne erfaring synes at være, at Foucault fra nu forbinder enhver ægte politisk aktivisme med et element af risiko og selv-opofrelse. For det andet udgør Foucaults 'politiske erfaring' også en erfaring på et mere teoretisk niveau. Det er her marxismen kommer ind i billedet. De tunesiske studerendes oprør var nemlig ifølge Foucault med til at rive ham løs fra en bestemt opfattelse af Marx. Han forklarer det på følgende måde:

Jeg husker de kølige akademiske diskussioner om marxismen, som jeg deltog i i Frankrig i begyndelsen af tresserne. I Tunesien derimod, appellerede alle til marxismen med en radikal voldsomhed og intensitet, og med en imponerende entusiasme. For disse unge mennesker udgjorde marxismen ikke bare en bedre måde at analysere virkeligheden: Den udgjorde samtidig en form for moralsk energi, en form for eksistentiel handling, der var ganske bemærkelsesværdig (Foucault 2000: 280).

Man fornemmer klart Foucaults sympati for denne eksistentielle, aktivistiske 'brug' af Marx. Noget tyder da også på, at de tunesiske studerendes entusiasme havde en vis effekt på Foucault. I hvert fald beskriver en af Foucaults biografer, James Miller, hvordan Foucault i forlængelse af begivenhederne i Tunesien igen begyndte at læse Karl Marx, Rosa Luxemburg, og Lev Trotskij (Miller 2000: 171). ${ }^{5}$ For det tredje udgør Foucaults politiske erfaring et brud med, hvad 
han selv beskriver som den 'spekulative skepticisme' i politiske anliggender, som hans skuffende ungdomsromance med det franske kommunistparti i 1950-1952 havde ført til (Foucault 2000: 279).

At karakterisere Foucaults erfaring med det tunesiske studenteroprør som hans 'politiske ilddåb' (Macey 1994: 209) er måske så meget sagt, men det er i hvert fald sikkert, at begivenhederne i Tunesien bliver startskuddet til et særdeles aktivt politisk engagement, da Foucault vender tilbage til Frankrig i efteråret 1968 for at indtage positionen som leder af det filosofiske institut på det nystiftede eksperimentelle universitet Vincennes i Paris.

\section{Gauche Prolétarienne og GIP}

Det Frankrig, som Foucault returnerer til i slutning af 1968, var stadig stærkt præget af begivenhederne i maj. Der blev således fortsat udført strejker og andre politiske aktioner rundt om i landet. Mange af disse aktioner blev organiseret af forskellige maoistiske grupperinger, hvoraf Gauche Prolétarienne (GP) var den største og mest kendte, støttet af en række prominente intellektuelle som Jean-Luc Godard, Jean Paul Sartre, Simone de Beauvoir og Maurice Clavel. Blandt de ledende skikkelser i disse grupper var en række af Louis Althussers tidligere studerende fra École Normale Supérieure. Og flere af disse unge filosoffer, nemlig Alain Badiou, Jacques Rancière, Judith Miller og Jacques-Alain Miller, var at finde i det af Foucault sammensatte lærerkollegium på det filosofiske institut på Vincennes. Også Foucaults partner, Daniel Defert, der ligeledes var ansat på Vincennes, var aktiv i Gauche Prolétarienne (Macey 1994: 217-218). Selvom maoismen således gennemsyrerede ikke blot Vincennes, men store dele af det franske venstreorienterede åndsliv i perioden 1966-1974, er dens eventuelle påvirkning af Foucaults tænkning stadig et temmelig uudforsket kapitel i receptionslitteraturen. ${ }^{6}$

I sin bog, The Wind from the East, om de franske 68er-intellektuelle og maoismen giver Richard Wolin en fyldig beskrivelse af, hvorledes Foucault efter sin hjemkomst fra Tunesien begynder at interessere sig for de maoistiske grupper (hovedsagligt GP), som på det tidspunkt spiller en central rolle $i$ det parisiske studentermiljø. Wolin giver også et bud på, hvori denne interesse bunder; han kobler den nemlig sammen med Foucaults 'tunesiske erfaring'. 
Eller, som han skriver: "Foucault var dybt imponeret over les gépistes, eller GP-medlemmerne, som syntes at legemliggøre de samme 'ultra' kvaliteter, som han havde beundret hos sine tunesiske studerende" (Wolin 2010: 301). ${ }^{7}$

Gauche Prolétarienne, der som sagt var den største af de franske maoistiske grupper, opstod i 1968 som en sammensmeltning af to venstreradikale grupper, den såkaldte Movement du 22 mars, som var studenteroprørets drivende kraft og så Union des Jeunesses Communistes (marxiste-léniniste), som udsprang fra miljøet omkring Althusser på École Normale Supérieure (Bourg 2007: 51; se også Wolin 2010: 117-124). ${ }^{8}$ Ligesom maoismen mere generelt forstod GP sig i forlængelse af en marxistisk-leninistisk tradition, men også som et korrektiv til og en videreudvikling af denne tradition. De franske maoister delte det overordnede mål med den leninistiske marxisme, som det franske kommunistparti repræsenterede, dvs. at mobilisere proletariatet i en revolution af det kapitalistiske samfund. Men de var skeptiske overfor flere centrale aspekter ved den leninistiske marxismes opfattelse af, hvordan dette mål kunne opnås og fastholdes, og kom således til stå $\mathrm{i}$ et kritisk forhold til den på en række punkter. ${ }^{9}$ For det første understregede maoisterne i modsætning til en leninistisk opfattelse, at det er masserne selv, og ikke en parti-avantgarde, der skaber historien. Man må derfor lytte til og lade folket selv tale. Maoismen rummer således både et element af anti-autoritarisme og en markant repræsentationskritik. For det andet afviste maoisterne, at revolutionen skulle kunne forudsiges eller planlægges på baggrund af økonomiske og historiske analyser; den vil altid udspringe af en spontan massehandling. For det tredje påpegede maoisterne ikke blot vigtigheden af en stærk alliance mellem studenter og arbejdere; de fremhævede desuden nødvendigheden af, at den (intellektuelle) politiske aktivist altid har en praktisk forankring i konkrete situationer i modsætning til en 'blot' teoretisk forståelse af disse. Maoisterne var således yderst kritiske overfor leninismens 'videnskabelige' marxisme og rummede visse antiintellektuelle tendenser. For det fjerde var maoisterne præget af en vis mistro til traditionelle leninistisk-marxistiske organiseringsformer, hvilket bl.a. kom til udtryk i en voldsom polemik imod fagforeningerne og det franske kommunistparti. Det er på denne baggrund, at man skal forstå de tre aktiviteter, som var særlig kendetegnende 
for GP, nemlig den aktive deltagelse i massernes fabriksarbejde (établissement), undersøgelsen af folkets praktiske forhold (enquête) og forsøget på at oprette folkedomstole (tribunal populaire). ${ }^{10}$ Som vi skal se, kan man genfinde flere af de nævnte centrale træk ved den franske maoisme hos Foucaults gruppe for fangeinformation, hvilket som allerede antydet ikke er helt tilfældig, da GIP blev dannet i forlængelse af en aktion, som GP tog initiativ til, og da dens måde at indsamle viden på har den maoistiske 'undersøgelse' (enquête) som sin model.

I 1970 blev GP forbudt af den franske regering, og en række af organisationens medlemmer blev fængslet, bl.a. redaktøren for GP's avis La Cause du Peuple, Jean-Pierre Le Dantec. De arresterede GPere flyttede imidlertid blot deres politiske aktiviteter med sig ind i fængslet, og i september 1970 påbegyndte en gruppe fanger, organiseret af GP'erne, en sultestrejke med et krav om at få tildelt status som 'politiske fanger'. Fangerne fik dog hverken indfriet deres krav eller den ønskede bevågenhed $\mathrm{i}$ offentligheden, og aktionen varede således kun en måned. Men i begyndelsen af 1971 indledte GP en bølge af bedre organiserede sultestrejker og krævede nu, at alle fanger (ikke blot dem, der var blevet dømt i henhold til de love, som var rettet imod GP) blev anerkendt som politiske fanger, da enhver overtrædelse af bourgeoisiets love ansås som en politisk handling (Wolin 2010: 199-203). Denne anden bølge af sultestrejker vakte, som han forklarer i et interview samme år, Foucaults opmærksomhed (Foucault 2001a: 1072). Samtidig var han blevet opfordret af GP til at involvere sig i fængselssagen (Bourg 2007: 79). Det blev anledningen til, at Foucault sammen med bl.a. Gilles Deleuze på en pressekonference i februar 1971 lancerede Groupe d'information sur les prisons med det formål at indsamle og videreformidle informationer om forholdene i de franske fængsler. GIP havde således, som Daniel Defert bemærker, hverken sit udspring fra GP eller fra Foucault, men fra et sted i mellem dem (Bourg 2007: 80).

Selvom GIP ikke identificerede sig eksplicit med Gauche Prolétarienne, hentede gruppen som nævnt afgørende inspiration fra maoisterne. Som bl.a. Wolin påpeger satte denne inspiration sig endvidere tydelige spor i Foucaults akademiske arbejde. Eller med Wolins egne ord: 
Foucaults periode med maoistisk inspireret militant politisk aktivisme er blevet meget lidt gransket. Men hvis man søger at få indsigt i udviklingen af foucauldianske begreber som 'genealogi', 'biomagt', og 'disciplinsamfundet', er en forståelse af denne periode afgørende, for det var som et resultat af hans arbejde med maoisterne, at Foucault kom frem til forestillingen om 'magtens mikrofysik', hvilket blev kendetegnende for hans senere arbejde (Wolin 2010: 18).

Foucault taler godt nok ikke selv om (maoistisk) inspiration, men han beskriver arbejdet i GIP som en erfaring/eksperiment (fr.: expérience) (Foucault 2000: 281) og signalerer hermed, at hans engagement i GIP rummer både et personligt og et transformativt element. Endvidere knytter han flere steder denne personlige-politiske erfaring sammen med sit teoretisk-analytiske arbejde, f.eks. i forordet til Overvågning og straf, hvor han skriver følgende: "At straffene i al almindelighed og fængslet i særdeleshed beror på en politisk teknologi for kroppen, er det måske mindre historien end nutiden, der har lært mig" (Foucault 2002: 44). Vi vil nu se nærmere på relationen mellem Foucaults erfaring med GIP og hans teoretiske overvejelser og forsøge mere præcist at efterspore en maoistisk inspiration.

\section{Undersøgelsen (enquête)}

Ud over at GIP altså til dels opstod på opfordring af Gauche Prolétarienne, viser den maoistiske inspiration sig tydeligst og mest konkret i form af GIPs brug af den såkaldte 'undersøgelse' (enquête), der var et helt centralt element $\mathrm{i}$ de franske maoistiske gruppers politiske aktivitet (Wolin 2010: 18). Det var Mao selv, der i 1930 i teksten Imod bogdyrkelse, lancerede 'undersøgelsen' som en afgørende forudsætning for teoretisk refleksion og politisk autoritet under sloganet: "Hvis ikke du selv har undersøgt et problem, så er du frataget retten til at udtale dig om det" (Mao 1930: 1). Eller, som han uddyber i forordet til hans Rapport om en undersogelse af bondebevagelsen $i$ Hunan: "Enhver, der er engageret i praktisk arbejde, skal undersøge forholdene på de lavere niveauer. En sådan undersøgelse er især nødvendigt for dem, der kender teorien, men ikke kender de faktiske forhold, for ellers vil de ikke være i stand til at koble teori med praksis" (citeret fra Bosteels 2005: 579). I Imod bogdyrkelse skitserer Mao i syv punkter det, han kalder 'undersøgelsens teknik', altså en række kon- 
krete retningslinjer for, hvordan en undersøgelse fortages. Denne teknik, eller i hvert fald væsentlige elementer fra den (særligt punkt 4 om spørgeskemaer) bliver GIPs vigtigste og mest brugte fremgangsmåde i deres arbejde med at indsamle og viderebringe informationer om de franske fangers forhold (Bourg 2007: 52; Wolin 2010: 303-306; Hoffman 2012: 26).

Mens både Wolin og Bourg nævner 'undersøgelsen' i deres behandling af den franske maoisme, finder man mere systematisk behandling af 'undersøgelsen' i Kristin Ross' bog May '68 and its Afterlives. Her beskriver Ross 'undersøgelsen' på en måde, der resonerer ganske godt med de ovenfor opridsede generelle træk ved den franske maoisme. 'Undersøgelsen' er for det første en teknik, som har til formål at omgå eller kortslutte de repræsentationssystemer, hvorigennem masserne fremstilles på borgerskabets præmisser, og som derfor har en undertrykkende funktion (Ross 2010: 109). For det andet, er 'undersøgelsen' en teknik, der med sit implicitte krav om 'direkte' og 'personligt' engagement lægger større vægt på lokale forhold og historiske omstændigheder - den konkrete situation - end på kanoniske og teoretiske tekster (Ross 2010: 109). 'Undersøgelsen' defineres således i opposition til traditionelle teoretiske vidensformer som arbejdssociologi og politologi (Ross 2010: 111-112). For det tredje implicerer 'undersøgelsen' en bestemt opfattelse af den intellektuelle:

Fordyb dig i 'massernes skole'; den intellektuelles rolle bør ikke være sociologens, hygiejnikerens, lærerens eller leninismens fortrop, men i bedste fald jordemoderens: at fremkalde revolutionære aspirationer, som allerede findes $i$ en latent tilstand, fremme deres udtryk og derefter syntetisere dem og sende dem tilbage i form af politiske udsagn. Saml nyhederne om kampen, beskriv den, returner det i en ny form, cirkuler det, reproducer det, gør dig selv til medium (Ross 2010: 110).

Et fjerde træk ved undersøgelsen, som fremgår implicit af citatet ovenfor, og som Bourg (2007: 52) ekspliciterer i sin behandling, er, at den viden, der kommer ud af undersøgelsen, tænkes strategisk som et indspil i en politisk kamp. Som flere kommentatorer bemærker, bliver undersøgelsen desuden et vigtigt redskab i opgøret med samtidens traditionelle marxisme. Eller, som Bourg formulerer det: 
Den maoistiske 'undersøgelse' fik en fremtrædende position på dette tidspunkt. Den skulle vise sig at blive afgørende i mobiliseringerne omkring fængslerne, og utilsigtet, $\mathrm{i}$ at komme hinsides den franske marxisme-leninisme" (Bourg 2007: 79; se også Ross 2010: 110, Wolin 2010: 131).

De undersøgelser, GIP udførte, blev lavet på baggrund af en (ulovlig) omdeling af spørgeskemaer vedrørende forholdene i fængslerne til indsatte via deres familiemedlemmer, tidligere straffede, advokater og socialrådgivere. De indsamlede oplysninger fra spørgeskemaerne tjente derefter som grundlag for offentliggørelse af resultaterne af undersøgelserne. GIP udsendte i perioden 19711973 fire sådanne udgivelser under titlen 'undersøgelser af utåleligheder' (Enquêtes-Intolérables) (Hoffman 2012: 26; Wolin 2010: 306). I forordet til GIPs første offentliggjorte undersøgelse, "Préface à enquête dans vingt prisons" (Forord til undersøgelse i tyve fængsler), skitserer Foucault, der er forordets forfatter, målet med og fremgangsmåden i gruppens undersøgelser (Foucault 2001b). For det første understreges det, at undersøgelserne er tænkt som en politisk handling og som led i en social kamp. Eller som Bourg bemærker: "[...] GIP gjorde meget for at advokere for 'undersøgelsen' som en form for 'kamp' i sig selv." (Bourg 2007: 48) For det andet har undersøgelserne altid 'specifikke mål', dvs. de tager afsæt i en konkret og lokal problematik. For det tredje udføres undersøgelserne ikke af en udefra kommende gruppe af teknikere, men af de involverede selv. Denne sidste og væsentlige pointe gentager Foucault i et samtidigt interview: "GIP agter ikke at tale for fangerne i forskellige fængsler: Gruppen agter tværtimod at give dem mulighed for at tale for sig selv og sige, hvad der sker i fængslerne" (Foucault 2001a: 1072). Vi genkender her tydeligt flere af maoisternes centrale anliggender: sammenkædningen af viden og kamp; udgangspunkt i den lokale og partikulære kontekst (i modsætning til det universelle perspektiv); opgøret med repræsentationstænkning og særligt forestillingen om, at teoretiske 'specialister' kan fungere som massernes eller bestemte undertrykte gruppers repræsentanter. Ligeledes aner vi en række af Foucaults senere ideer: det gensidige forhold mellem viden og magt; hans skepsis overfor 'globale' teorier og hans begreb om magtens mikrofysik i hverdagslivets relationer; modstillingen mellem den universelle og den 'specifikke' 
intellektuelle. ${ }^{11}$ Foucault bekræfter da også denne anelse i forhold til hans revidering af magtbegrebet. I et interview fra 1977 udtaler han således:

Der kom et tidspunkt, hvor denne [traditionelle, negative opfattelse af magt] slog mig som utilstrækkelig. Det var i forbindelse med en konkret erfaring, jeg havde med fængsler, der startede i 1971-1972. Sagen om straffesystemet overbeviste mig om, at spørgsmålet om magten skulle formuleres ikke så meget i juridiske termer som i termer som teknologi, taktik og strategi, og det var denne udskiftning af en juridisk og negativ ramme med en teknisk og strategisk, som jeg forsøgte at foretage i Overvagning og straf, og derefter at udnytte i Seksualitetens historie (Foucault 1980c: 184).

Intervallet mellem disse to bøger, Overvagning og straf og Seksualitetens historie, udgør således en af de perioder i Foucaults forfatterskab, hvori han mest intensivt beskæftigede sig med magtbegrebet. Det kommer bl.a. til udtryk i den forelæsningsrække, han holdt på Collège de France i 1976 med titlen Samfundet må forsvares. Her udforskende han magtkonceptionen i den moderne historieskrivning for på den måde at problematisere og revidere sin egen samtids magtopfattelse. Denne forelæsningsrække rummer samtidig Foucaults mest eksplicitte overvejelser over hans genealogiske historieskrivning, især hvad angår dennes relation til sociale og politiske konflikter. Vi vil nu i den resterende del af artiklen forsøge at vise specifikt, hvordan flere af de ovenfor belyste 'maoistiske' elementer reflekteres i disse overvejelser.

\section{Samfundet må forsvares}

Foucaults forelæsningsrække fra 1976 er kendt som dér, hvor Foucault anvender 'krig' som den grundlæggende optik for at forstå politik og statsdannelse, idet "politik kan anskues som krig med andre midler" (Foucault 2003: 16). Måske huskes forelæsningerne også for Foucaults provokerende påstande om, at racehygiejne og biologisk racisme udgør et internt element $i$ alle moderne statsregimer, herunder stalinisme og nationalsocialisme (Foucault 2003: 260). Men i øvrigt har denne forelæsningsrække ikke modtaget megen opmærksomhed i dansk sammenhæng. ${ }^{12}$ I det følgende vil vi vise, 
at forelæsningsrækken udgør et velegnet afsæt for at diskutere Foucaults begreb om genealogi og dets relation til marxisme og maoisternes praksis. Forelæsningerne fremviser således iøjnefaldende teoretisk-metodiske paralleller til de aktivistiske principper hos de franske maoister. Samtidig rummer de både kritiske kommentarer til samtidens teoretiske marxisme og skarpe udfald mod den virkeliggjorte marxisme i skikkelse af stalinisme (men også socialdemokratisme), hvilket giver forelæsningerne karakter af en kompleks dialog med både den teoretiske og praktiske marxisme.

Sammenligner man Foucaults forskellige formuleringer af den genealogiske strategi, er hans betoning af 'lokal', 'udgrænset' og 'autonom' viden bemærkelsesværdig i Samfundet må forsvares. Dette er den ikke mindst i betragtning af, at disse indledende kommentarer fremstår temmelig løsrevet fra indholdet i de efterfølgende historiske forelæsninger. Foucault betoner vedholdende $\mathrm{i}$ de første forelæsninger, at det er en afgørende opgave for genealogien at producere en viden, som ikke umiddelbart kan annekteres af overgribende teoridannelser, at "modsætte sig og kæmpe mod den formelle, videnskabelige-teoretiske diskurs' tvang" (Foucault 2003: 10). I denne sammenhæng fremfører Foucault et velkendt kritikpunkt mod teoretisk marxisme, nemlig dens priviligering af sin egen position og dens diskvalificering af alternativ viden gennem distinktionen videnskab/ideologi. Den teoretiske marxismes forfægtelse af at udgøre en videnskab er for Foucault en diskursiv strategi, der gyldiggør egne aksiomer, hævder at repræsentere undertrykkelsens former og har som funktion at ekskludere andre, 'inferiøre' vidensformer (Foucault 2003: 10-15). I modsætning til en sådan centraliseret og institutionaliseret viden henviser Foucault til en type autonom vidensproduktion, som er blevet muliggjort af de senere års fremkomst af en tiltagende 'lokal kritik' (Foucault 2003: 6); en term, der kan tænkes at inkludere Foucaults egen aktivisme i GIP. Den lokale kritik rummer et alternativt kritisk potentiale, men Foucault ser en risiko for, at den bliver annekteret af uniforme vidensdiskurser og doktrinære politiske programmer.

Hvis en strategi for maoisterne bestod $i$ at udøve taktikker og former for politisk kamp, som ikke umiddelbart kan approprieres og indsættes i en traditionel partipolitisk organisationsform, så genspejles denne strategi på et analytisk niveau i Foucaults formulerin- 
ger af genealogiens virksomhed (Foucault 2003: 9-19). Han siger således, at det handler om at ophæve den overgribende diskurs' tyranni ved at mobilisere lokal, diskvalificeret og inferiør viden imod den. Det drejer sig om, ligesom maoisterne var sig bevidste, at undgå at udøve en (videns)praksis, som leder til geninstallationen af de magtapparater (hierarkisk parti-organisation) og diskurser (autoriseret videnskab), som den kritiske praksis netop var et opgør med. De to dominerende kritiske vidensformer i Foucaults samtid, psykoanalysen og marxismen, udgør i hans optik netop repræsentanter for en abstrakt og uniform diskurs, som ikke har leveret redskaber til brug for kampe på det lokale plan. De kan, ifølge Foucault, kun levere sådanne, såfremt deres teoretiske enhed bliver

om jeg så må sige, suspenderet, eller i det mindste skåret op, revet fra hinanden, flået i stykker, vendt på vrangen, fortrængt, karikeret, dramatiseret og så videre. [...]. Jeg mener, at kritikkens essentielle lokale karakter faktisk udpeger noget, som ligner en art autonom og ikke-centraliseret teoretisk produktion, eller med andre ord, en teoriproduktion, som ikke behøver noget visum fra et alment regime for at bekræfte sin gyldighed (Foucault 2003: 6).

Flere steder fremhæver Foucault faren for, at viden bliver erobret, indrulleret og anvendt af en overgribende instans - staten, den videnskabelige institution eller partiet. Genealogen må konstant have øje for risikoen for en sådan annektering, og må søge at yde modstand mod "de centraliserende magteffekter, som følger af institutionaliseringen af viden" (Foucault 2003: 9). Midlet hertil består, ifølge Foucault, i koblingen af den lokale, udgrænsede viden med historikerens faglige kunnen, som kan producere en viden, der vanskeligt lader sig indoptage i totale og unitære systemer. Det er iøjnefaldende, at Foucault tilbagevendende fremhæver, at genealogien bør bekæmpe de uniforme, autoriserede, videnskabelige regimer og institutioner (Foucault 2003: 7, 9-12). Her anes et ekko af maoisternes kritik af autoriserede videnskaber - arbejdssociologien, politologien, retsvidenskaben - som uanvendelige redskaber i en kritisk praksis, der skal muliggøre de undertryktes selv-repræsentation.

At analysere samfund og statsdannelse 'gennem krigens register' udgør ifølge Foucault en strategi mod de autoriserede videnskabers repræsentationsmonopol og magteffekter. Det er et analytisk 
register, der anskuer vedvarende sociale stridigheder som grundlæggende for ethvert samfund og dets historie (Foucault 2003: 156, 162). Foucault påpeger, at de formelle institutioner, love og forfatninger tjener til at maskere de kampe mellem sociale grupper, som blot har fundet en midlertidig fiksering i statens tilsyneladende neutrale orden. Man bør påvise, at der "under statens formelle facade eksisterede andre kræfter, og at disse netop ikke var statens kræfter, men en partikulær gruppes kræfter med dens egen historie, dens egen relation til fortiden, dens egne sejre" (Foucault 2003: 224). Foucault har særlig sympati for 'den historisk-politiske diskurs' - en række 1700- og tidlige 1800-tals forfattere bl.a. Henri de Boulainvilliers, Augustin Thierry og Jacob N. Moreau, der gjorde kampe mellem folkeslag, såkaldte 'race-krige', til det ustabile grundlag for staters dannelse og omdannelse. Et vigtigt motiv for sympatien med dette konfliktperspektiv er, at det grundlæggende udfordrer de autoriserede videnskaber. Disse tager netop afsæt i forfatninger, love og formelle institutioner, eller 'statens formelle facade', når magtspørgsmål adresseres. Hermed skygger de ikke blot for undersøgelser af magtens mikropraksisser og sociale kampe og herredømme-forhold under forfatningen; de risikerer ligefrem at annektere og rekodificere den lokale, kritiske viden, således at den passer ind $\mathrm{i}$ lovens og institutionernes kategorier. Foucaults interesse for den historisk-politiske diskurs, der søger under forfatningen, kan ses som en parallel til maoisternes skepsis overfor 'borgerlige institutioner', som hverken er i stand til at repræsentere de undertrykte eller beskytte dem i praksis. En skepsis som bl.a. kom til udtryk i maoisternes førnævnte krav om oprettelse af folkedomstole som alternativ til de borgerlige retsinstanser (Foucault 1980a; Wolin 2010: 28-31; Bourg 2007: 68-78).

Som et ekko af maoisternes strategi om at bruge lokale undersøgelser som afsæt for kritisk virksomhed fremfører Foucault, at magten bør undersøges i dens mikropraksisser, dér hvor den bliver kapillær: "At forstå magten i dens mest regionale former og institutioner, og især i de punkter, hvor denne magt rækker ud over de retslige koder, som organiserer og afgrænser den, overskrider disse koder og bliver forankret i institutioner og indlejret i teknikker." (Foucault 2003: 28). Dette begreb om 'mikromagt' er ofte blevet fortolket som et metodisk princip, der skal føre magtanalytikeren 
bort fra abstrakt teoretiseren over magten (stat, ideologi) og mod dens konkrete organisering (teknikker, praksisser). Men det ser ud til, at princippet også har en klar praktisk, aktivistisk dimension. Dette bliver tydeligt, når Foucault påpeger, at overfor en sådan mikromagt er det uvirksomt at appellere til den suveræne ret (Foucault 2003: 39). Eftersom magten har overskredet lovens ramme og ikke begrænses af den, kræves netop specifikke undersøgelser af dens udøvelse i praksis, i lighed med den maoistiske undersøgelse.

En yderligere bemærkelsesværdig parallel til den maoistiske virksomhed er Foucaults håndtering af repræsentationsproblemet i Samfundet må forsvares. I stedet for selv at indtage pladsen som forfatter og kritikker lader Foucault konsekvent de historiske skribenter selv tale og således indirekte udøve en type kritik, som Foucault påpeger, at han ikke blot undersøger, men ligefrem "lovpriser" (Foucault 2003: 111). Frem for selv at søge at repræsentere de undertrykte eller fremføre en politisk teori om statsdannelse er det Foucaults taktik at lade denne delvist glemte 'historisk-politisk diskurs' udføre kritikken implicit. Dette sker via genfremstilling af et historisk kildemateriale, hvor "krig gennemtrænger samfundet og dets historie" (Foucault 2003: 156; 162). Det afgørende er ikke at repræsentere stridighederne, de underkuede eller konkrete historiske begivenheder på en endegyldig sand måde. De historiske skribenter tilbyder snarere, med Foucaults ord, en 'forståelsesoptik', en alternativ prisme til at begribe statsdannelse og politik igennem (Foucault 2003: 163).

Men faktisk går Foucaults læsning et skridt videre, idet den 'historisk-politiske diskurs' viser, at der ikke findes nogen neutral position, hvorfra historie og samfund kan repræsenteres. Tværtimod indgår historieskriveren uundgåeligt $i$ en kamp om at sige sandheden - om staten, nationen, krigene, blodets bånd og hvem der er retmæssige arvtagere til territoriet. Foucaults skribenter anerkender, at der ikke gives et universalistisk, objektivt udgangspunkt for at bestemme statens forfatning, love eller rettigheder. Historikeren indtager således ikke en repræsentationsfunktion eller optræder som fortaler for universelle værdier, men optræder uundgåeligt som "et subjekt, der udkæmper en krig" (Foucault 2003: 54). Hvis vi generaliserer denne pointe, dukker der i 1976-forelæsningerne en kritisk iagttager op, som både undgår at tage udgangspunkt i 'de 
undertrykte' som en stabil eller transcendent kategori og i arbejdere/ borgerskab som grundlæggende og forud given modsætning. I stedet fremstår klassen, staten, folket og nationen som ikke-transcendente, fluktuerende kategorier, ligesom sociale kampe og herredømmeformer fremstår som omskiftelige og ikke-fundamentale. Foucaults sympati for et sådant konfliktperspektiv på historien, som gennemstråles af stridende rationaliteter, er ofte blevet henvist til hans overtagelse af Nietzsches opfattelse af historien som de stridende kræfters evige spil. Ved at relatere Foucaults maoistiske engagement direkte til hans refleksioner i 1976-forelæsningerne fremkommer imidlertid en væsentlig alternativ faktor, nemlig en række praktisk-aktivistiske og socialt situerede erfaringer, som medvirkede afgørende til formuleringen af den genealogiske strategi.

Vores argument i denne artikel er ikke, at vi bør erstatte Foucaults relation til Nietzsche med hans relation til maoistisk aktivisme for bedre at forstå hans begreb om genealogi. Følgelig er vores ærinde heller ikke, at vise, at den egentlige reference, ur-teksten, for Foucaults genealogiske metode er Samfundet må forsvares og ikke Nietzsche - genealogien, historien (Foucault 2001c). Pointen er snarere, at 1976-forelæsningerne udgør den øjensynligt klareste formulering af Foucaults genealogiske metode - ikke mindst af genealogiens uomgængelige relation til sin samtids politiske, sociale og intellektuelle konflikter. Implicit heri ligger således, at den hidtidige udbredte konsensus om Nietzsche - genealogien, historien som Foucaults centrale bestemmelse af genealogien kan debatteres. Snarere end at bestemme Foucaults egen genealogiske metode udgør dette essay en detaljeret, omend fragmenteret (ikke-metodisk) kommentar til Nietzsches historiesyn (se også Mitchell Dean1994: 14ff). Hvor Foucaults essay om Nietzsche er akademisk situeret, idet det udgør en af Foucaults relativt få eksplicitte fortolkninger af en anden tænkers værk, så er hans bestemmelse af genealogien i 1976-forelæsningerne snarere situeret $\mathrm{i}$ en aktuel politisk-social kontekst.

I Nietzsche - genealogien, historien finder Foucault hos Nietzsche en koncipering af genealogien som et angreb på enhver historisk eller metafysik forestilling om oprindelige, immobile instanser bagved historiens tildragelser. Især ryster genealogien den forestilling om subjektets enhed og kohærens, som historikere ifølge Foucault har tilbudt den identitetssøgende europæer, ved at afdække de diskontinuære begivenheder og stridende fortolkninger, som gennemskærer enhver identi- 
tet. Genealogien må registrere begivenhedernes singularitet uden at henvise dem til et overhistorisk princip eller en syntetiserende enhed, men derimod finde dem i herredømmeforholdenes tilfældige spil. I Foucaults læsning er den basale metode i Nietzsches wirkliche Historie at fragmentere det, der fremstår selvberoende, kohærent og selv-identisk.

Der må imidlertid også anerkendes tydelige paralleller mellem Foucaults bestemmelse af genealogien i Nietzsche-essayet og 1976-forelæsningerne. Det gælder for det første betoningen i begge sammenhænge af, at begreber om universalisme, frihed, eller en retfærdig retsorden altid hviler på et midlertidigt herredømme. Menneskeheden skrider ikke gradvist fremad fra kamp til kamp for til sidst at etablere en universel social orden, hvor lovens neutralitet endegyldigt erstatter krigene. I begge sammenhænge søger genealogien at påvise, at vi bevæger os fra én form for dominans til en anden. For det andet indebærer idéen om, at historieskrivning er en endeløs serie af stridende fortolkninger, at historikeren aldrig blot kan være en objektiv arkivar, men uundgåeligt bliver en aktør i de stridende kræfters spil. For det tredje kan Nietzsche-essayets opgør med enhver forestilling om identitet og oprindelighed nemt overføres til 1976-forelæsningernes sympati for historieskrivere, der problematiserer sociale identiteter såsom 'folk', 'racer' og 'nationer'. I begge tilfældevælger genealogen at angribe dér, hvor mennesket foregiver at besidde en kohærent identitet, for at udrede de mangfoldige tilfældigheder og sammenstød, hvis spor nemt opfanges af det historisk trænede øje. Mens Foucault således begge steder fremhæver genealogiens grundlæggende funktion som fragmentering, der fremviser, at identiteter og institutioner har en broget historisk opkomst i stridigheder, tilfældigheder og løbende genfortolkninger, er der forskel med hensyn til, hvad det er for begrænsninger, som genealogien adresserer $\mathrm{i}$ hvert tilfælde. Nietzsche-essayet betoner opgøret med den metafysiske forestilling om transcendentale instanser, mens Samfundet må forsvares snarere betoner, hvordan den genealogiske udgravning kan afdække forudgående sociale kampe i relation til hegemoniske sociale ordener, og hvordan genealogisk viden indgår i samtidens institutionelle, politiske og kulturelle konflikter. Endelig er Foucaults betoning i 1976 af nødvendigheden af en genealogisk vidensproduktion, som yder modstand mod insti- 
tutionel annektering og beherskelse, måske den pointe, som tydeligst genklinger af de maoistiske principper. Idéen om den svært institutionalisérbare viden er distinkt for hans formulering af genealogien i 1976 og kan desuden ses i lyset af hans udtalte forsøg på at undslippe dem, der søgte at identificere hans arbejde som tilhørende den ene eller den anden politiske lejr. Spredningen af 'den sovjetiske model' til det franske politiske og intellektuelle miljø i 1970'erne skabte, ifølge Foucault, en odiøs "verden af fjender", hvor alt drejede sig om at finde ud af, til hvem man havde troskab i et system af rigide skillelinjer og fjendskab (Foucault, Gordon og Patton 2012: 107). At Foucault også tager bestik af denne samtidskontekst, synes at anes i hans 1976-formulering af genealogiens metode, hvorved genealogiens karakter af intervention i sin egen politiske (og ikke blot akademiske) kontekst atter betones.

\section{Konklusion}

I denne artikel har vi forsøgt at bedrive en form for idéhistorie over Foucaults særlige historieskrivning ved at oprulle en hidtil underbelyst inspirationskilde til Foucaults bestemmelse af sin genealogiske tilgang, nemlig den franske maoisme og hans engagement i GIP. Især har vi forsøgt at efterspore, hvordan den maoistiske undersøgelse, som GIP benyttede sig af, har sat sig spor i Foucaults tænkning. Disse spor omfatter nærmere bestemt Foucaults formulering af det gensidige forhold mellem viden og magt, hans skepsis overfor 'globale' teorier, hans begreb om magtens mikrofysik i hverdagslivets relationer og hans modstilling af den universelle og den 'specifikke' intellektuelle. Vores pointe har hermed også et genealogisk islæt i den forstand, at vi håber, at vores artikel måske kan være med til, hvis ikke ligefrem at problematisere og 'ryste' en nutidig selvfølgelighed, så dog supplere og nuancere den dominerende læsning af Foucaults genealogiske historieskrivning som grundlæggende antimarxistisk og nietzscheansk.

I 1970erne er Foucault, som vi har påpeget, praktisk engageret i forskellige former for politisk aktivisme i GIP. På samme tid stilles han overfor krav om at bringe sine magtkritikker op på et mere generelt niveau og teoretisere statens rolle mere præcist. Foucault bemærker om kritikkerne af hans manglende statsteori: "Nogle siger, at jeg negligerer dens rolle, andre, at jeg ser den alle vegne" (Foucault 1991: 85). Men han afviser selv at etablere en general magtteori eller statsteori. Begge 
forhold udgør en ramme for at forstå Foucaults overraskende selvkritiske kommentarer i indledningen til 1976-forelæsningerne om, at hans tidligere arbejde havde fejlet ved at være sporadisk, fragmenteret og ikke kunne syntetiseres (Foucault 2003: 3-4). Trods disse tilsyneladende indrømmelser gør Foucault ikke det, han bliver bedt om: at teoretisere statens rolle som magtudøver. Faktisk ligger ideen om at syntetisere sine tidligere 'fragmenterede' undersøgelser i en global teori, en "teoretisk kongekrone", som skulle forene dem, Foucault fjernt (Foucault 2003: 12). I stedet bruger han i de første forelæsninger meget taletid på at påpege de problematiske aspekter ved netop uniforme og overgribende videnskabelige diskurser. Først og fremmest er den parallel og sammenkoblet med statslige institutioner til normalisering og social udrensning af de truende og afvigende. Men den overgribende diskurs er også forbundet med en abstrakt, marxistisk teoridannelse, som er selv-legitimerende, hævder at repræsentere de undertrykte og er isoleret fra hverdagslivets sociale kampe. Denne type diskurs er, ifølge Foucault, knyttet til partiformen med dets hierarkier, formalisme og tendens til magtmonopolisering (den implicitte kritik af det franske kommunistparti er her åbenbar). Alt i alt er der en række tydelige paralleller mellem de maoistiske principper for politisk kamp og Foucaults akademiske principper for historieskrivningen som kampplads. Hvor den maoistiske aktivist undviger at tage udgangspunkt i 'de undertrykte' som forud given kategori til fordel for studier af undertrykkelsens konkrete praksisser, så anerkender den genealogiske historieskriver, at stater, klasser og folkeslag ikke udgør grundlæggende kategorier, men skabes $i$ kraft af diverse praksisser. Disse praksisser må undersøges $i$ detaljen for at blive i stand til at kaste et kritisk lys på de herredømmeformer og fikserede sociale kampe, som statens hegemoni og dens institutioner er funderet på. Den overgribende og ekskluderende teoridannelse udfordres af maoisten ved at blotlægge de undertryktes faktiske vilkår og egne stemmer, mens Foucault fra kateteret udfordrer den ved at genintroducere en historisk diskurs, der ser sociale stridigheder som grundlæggede for enhver stat, og fremhæver det uundgåeligt strategiske i enhver påstand om at repræsentere folket, de undertrykte og historien. Når Wolin fremsætter den tese, at Foucaults genealogiske studier af biopolitik, disciplin og guvernementalitet i 1970erne må forstås 
i sammenhæng med hans samtidige politiske aktivisme, giver vi hamret. Vi har her begyndt undersøgelsen af denne sammenhæng, men der er fortsat mange aspekter heri, som fortjener yderligere udforskning.

\section{Noter}

1 Hvis intet andet fremgår, er oversættelserne forfatternes egne.

2 Her udpeges Nietzsche ofte som den figur, der tillader Foucault at frigøre sig fra den i hans samtid herskende marxistiske (hegelianske) tænkning og som den, der leverer ammunition til hans opgør med denne tradition. Det afviser Foucault dog selv: 'Interessen for Nietzsche og Bataille var ikke en måde at distancere os fra marxisme eller kommunisme på; det var den eneste vej til det, vi forventede os af kommunismen." (Foucault 2000: 249; se også Foucault 1997: 439).

3 Også Mark Poster (1985) har i sit 'tidlige' bidrag Foucault, Marxism and History et godt blik for de mere 'positive', og ikke kun de kritiske, aspekter i Foucaults forhold til marxismen.

4 Mark Kelly (2008: 18) bemærker i sin bog The Political Philosophy of Michel Foucault, at "Hvad angår udviklingen af hans politiske tænknings særegenhed var den mest afgørende begivenhed for Foucault hans ledende engagement i Groupe d'information sur les prisons [...]." Kelly uddyber desværre ikke sin bemærkning. Til gengæld findes der to mere dybdegående studier af den teoretiske betydning af Foucaults engagement i GIP, nemlig Wolin (2010) og Hoffman (2012), som vi til dels vil trække på i det følgende. Ingen af disse studier har dog relationen mellem Foucaults politiske aktivisme og udviklingen af genealogien som eksplicit fokus.

5 Eric Paras bemærker i sin bog Foucault 2.0: Beyond Power and Knowledge, at der fra 1969 pludselig begynder at dukke en marxistisk terminologi op i Foucaults diskurs, der imidlertid fuldstændig er forsvundet igen omkring 1975 (Paras 2006: 57-62).

6 Vi kender således kun til to studier, nemlig Bourg (2007) og Wolin (2010). I det hele taget er det påfaldende få af Foucaults mange fortolkere, som - til trods for, at de fleste bekræfter vigtigheden af hans engagement i en række politiske sager gennem 1970erne - har forsøgt at belyse den nærmere sammenhæng mellem hans politiske erfaringer og hans teoretiske udvikling.En undtagelse her er Aray \& Andersons bog Foucault and the Iranian Revolutionog Brady Thomas Heiners studie "Foucault and the Black Panthers", samt en række nyere artikler om Foucaults engagement i GIP (Brich 2008; Welch 2010; Hofmann 2012). 
7 David Macey (1994: 217) fortager en lignende kobling: "Organiseret trotskisme var uden interesse for Foucault, men gauchisme havde helt bestemt en tiltrækning på ham. Han var blevet politiseret af, hvad han havde set og oplevet i Tunesien, og Daniel Defert bevægede sig i forvejen i gauchistiske kredse."

8 Althusser, der var et prominent medlem af det franske kommunistparti og som bidragede afgørende til den teoretiske fornyelse af den marxistiskleninistiske tradition i Frankrig, indtog en afvisende holdning overfor 68-oprøret, og kom således til at stå i opposition til flere af sine tidligere elever, der med inspiration fra bl.a. maoismen efter 68 kritiserede deres lærer. F.eks. Jacques Rancière (1974) og Alain Badiou (1976), der begge især kritiserede Althussers skel mellem ideologi og videnskab, som var af afgørende betydning for hans forsøg på at videnskabeliggøre marxismen.

9 Vi trækker her på de (ofte implicitte) refleksioner over forholdet mellem (leninistisk) marxisme og maoisme i Macey 1994: 217-219), Bourg (2007: 45-105), Ross (2010: 90-113) og Wolin (2010).

10 Foucault (1980a: 1-36) diskuterer i en offentliggjort samtale fra 1972 spørgsmålet om folkedomstole med to af de mest fremtrædende medlemmer af GP. Det er dog hans holdning til og brug af den maoistiske undersøgelsesteknik (enquête), der har vores interesse.

11 Både Bourg (2007: 4, 48,) og Wolin (2010: 308, 316) argumenterer for, at fængselspsykiateren Edith Rose, der under urolighederne i fængslet i Toul i december 1971 havde skrevet et åbent brev til fængselsadministrationen, hvori hun fremsatte en sønderlemmende kritik af den, udgør en væsentlig inspirationskilde til Foucaults gentænkning af den intellektuelles rolle (Foucault 1977a: 207-208; 1980b: 126-133). Som Bourg skriver: "Hendes [Edith Roses] afsløringer af den psykiatriske mishandling og sammenhængene mellem kriminalisering og patologisering indenfor det juridiske system tjente som model i Foucaults og Deleuzes senere samtale (4. marts 1972) for, hvad de omtalte som den 'specifikke intellektuelle' [...].”(Bourg 2007: 48).

12 En undtagelse er Kim Su Rasmussens artikel "Michel Foucault og racismens idéhistorie” (Su Rasmussen 2005). 


\section{Litteratur}

Badiou, Alain \& Balmès François, (1976): De l'idéologie, François Maspero: Paris. Balibar, Étienne (1992): "Foucault and Marx: The question of nominalism" i T.J. Armstrong (red.), Michel Foucault philosopher, New York: Routledge.

Bosteels, Brune (2005): "Post-Maoism: Badiou and Politics", Positions: East Asia Cultures Critique vol. 13, nr. 3, s. 575-634.

Bourg, Julian (2007): From Revolution to Ethics: May 1968 and Contemporary French Thought, Montreal: McGill-Queen's University Press.

Brich, Cecile (2008): “The Groupe d'Information sur les Prisons: The Voice of Prisoners? Or Foucault's?”, Foucault Studies 5, s. 26-47.

Callinicos, Alex (1990): Against Post Modernism: A Marxist Critique, London: Palgrave MacMillan.

Dean, Mitchell (1994): Critical and Effective Histories: Foucault's Methods and Historical Sociology,London: Routledge.

Dreyfus, Hubert L. \& Rabinow, Paul (1982): Michel Foucault: Beyond Structuralism and Hermeneutics, Chicago: University of Chicago Press.

Eagleton, Terry (1991): The Ideology of the Aesthetic, London: Wiley-Blackwell.

Foucault, Michel (1977a): "Intellectuals and Power" i D. Bouchard (red.), Language, Counter-Memory, Practice, Oxford: Blackwell.

Foucault, Michel (1977b): "Revolutionary Action: 'Until Now"', i D. Bouchard (red.), Language, Counter-Memory, Practice, Oxford: Blackwell.

Foucault, Michel (1980a): “On Popular Justice: A Discussion with Maoists”, i C. Gordon (red.), Power/Knowledge: Selected Interviews and Other Writings 1972-1977, New York: Pantheon Books.

Foucault, Michel (1980b): “Truth and Power", i C. Gordon (red.), Power/Knowledge: Selected Interviews and Other Writings 1972-1977, New York: Pantheon Books.

Foucault, Michel (1980c): “The History of Sexuality", i C. Gordon (red.), Power/ Knowledge: Selected Interviews and Other Writings 1972-1977, New York: Pantheon Books.

Foucault, Michel (1990): “The Return of Morality”, i L. D. Kritzman (red.), Politics, Philosophy and Culture - Interviews and Other Writtings 1977-1984, New York: Routledge.

Foucault, Michel (1991): “Questions of Method”, i G. Burchell, C. Gordon \& P. Miller (red.) The Foucault Effect: Studies in Governmentality, Chicago: The University of Chicago Press.

Foucault, Michel (1996): “On Attica”, I S. Lotringer (red.), Foucault Live - Collected Interviews: 1961-1984, New York: Semiotext[e].

Foucault, Michel (1997): "Structuralism and Post Structuralism", i Paul Rabinow 
(red.), Ethics - Subjectivity and Truth Essential Works of Foucault, 1954-1984, vol I. New York: The New Press.

Foucault, Michel (2000): "Interview with Michel Foucault", i: Paul Rabinow (red.), Power: Essential Works of Foucault, 1954-1984, vol. III, London: Penguin Books.

Foucault, Michel (2001a): "Je perçois l'intolérable" i Daniel Defert\& François Ewald (red.), Dits et écrits: 1954-1988, Tome II, Paris: Galimard.

Foucault, Michel (2001b): "Préface à Enquête dans vingt prisons" i Daniel Defert \& François Ewald (red.), Dits et écrits: 1954-1988, Tome II, Paris: Galimard.

Foucault, Michel (2001c): ”Nietzsche - genealogien, historien“ i Talens forfatning, København: Hans Reitzels Forlag.

Foucault, Michel (2002, [1975]): Overvagning og straf, Frederiksberg: Det lille Forlag.

Foucault, Michel (2003, [1997]): Society Must Be Defended: Lectures at the Collegge de France, 1975-76, New York: Picador.

Foucault, Michel, Gordon, Colin \& Patton, Paul (2012 [1978]): “Considerations on Marxism, Phenomenology and Power. Interview with Michel Foucault; Recorded on 3rd April 1978", Foucault Studies, 14, s. 98-114.

Hoffman, Marcelo (2012): “Foucault and the 'Lesson' of the Prisoner Support Movement", New Political Science, vol. 34, nr. 1, s. 21-36.

Hunt, Alan (2004): “Getting Marx and Foucault into Bed Together!", Journal of Law and Society, vol. 31, nr. 4, s. 592-609.

Kelly, Mark (2008): The Political Philosophy of Michel Foucault, London: Routledge.

Macdonald, Bradley J. (2000): "Marx, Foucault, Genealogy", Polity, vol. XXXIV, nr. 3, s. 259-284.

Macey, David (1994): The Lives of Michel Foucault, New York: Vintage Press.

Mahon, Michael (1992): Foucault's Nietzschean Genealogy: Truth, Power, and the Subject, Albany: State University of New York Press.

Mao Tse-Tung (1930): “Oppose Book Worship” http://www.marxists.org/ reference/archive/mao/selected-works/volume-6/mswv6_11.htm

Miller, James (2000, [1993]): The Passion of Michel Foucault, Cambridge: Harvard University Press.

Minson, Jeffrey P. (1986): Genealogies of Morals: Nietzsche, Foucault, Donzelot and the Eccentricity of Ethics, London: Palgrave Macmillan.

Olssen, Mark (2004): "Foucault and Marxism: Rewriting the Theory of Historical Materialism” Policy Futures in Education, vol. 2, nr 3 \& 4, s. 454-482.

Owen, David (1994): Maturity and modernity: Nietzsche, Weber, Foucault, and the ambivalence of reason, London: Routledge.

Paolucci, Paul (2002): "Foucault's Encounter with Marxism" i J.H. Lehmann 
(red.), Current Perspectives in Social Theory (Volume 22), Bingley: Emerald Group Publishing Limited.

Paras, Eric (2006): Foucault 2.0: Beyond Power and Knowledge, Cambridge: Harvard University Press.

Poster, Mark (1985): Foucault, Marxism, and History: Mode of Production Versus Mode of Information, London: Blackwell Pub.

Rancière, Jacques (1974): La leçon d'Althusser, Paris: Galimard.

Ross, Kirstin (2010): May '68 and Its Afterlives, Chicago: University Of Chicago Press.

Smart, Barry (1983): Foucault, Marxism and Critique, London: Routledge.

Su Rasmussen, Kim (2005): "Michel Foucault og racismens idéhistorie", Distinktion, vol. 6, nr. 2, s. 27-40.

Welch, Michael (2010): "Pastoral Power as Penal Resistance: Foucault and the Groupe d'Information sur les Prisons”, Punishment \& Society, vol. 12, nr. 1, s. 47-63.

Wolin, Richard (2010): The Wind from the East: French Intellectuals, the Cultural Revolution, and the Legacy of the 1960s, Princeton: Princeton University Press. 
